\title{
Processing and characterization of a Ni-Co ferrite for sensor applications
}

\section{(Processamento e caracterização de uma ferrita Ni-Co para aplicações em sensores)}

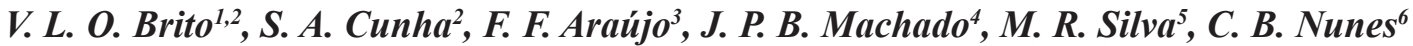 \\ ${ }^{I}$ Instituto de Estudos Avançados, USP, S. José dos Campos, SP, Brazil \\ ${ }^{2}$ Programa de Pós-Graduação em Ciências e Tecnologias Espaciais, \\ ${ }^{3}$ Programa de Pós-Graduação em Engenharia Aeronáutica e Mecânica, \\ Instituto Tecnológico de Aeronáutica, S. José dos Campos, SP, Brazil \\ ${ }^{4}$ Laboratório Associado de Materiais e Sensores, Instituto Nacional de Pesquisas Espaciais, \\ S. José dos Campos, SP, Brazil \\ ${ }^{5}$ Departamento de Física e Química, Universidade Federal de Itajubá, Itajubá, MG, Brazil \\ ${ }^{6}$ Escola de Engenharia de Lorena, Universidade de S. Paulo, Lorena, SP, Brazil
}

\begin{abstract}
Ni-Co ferrites are magnetostrictive ceramics that have potential application in magnetostrictive/ magnetoelastic sensors, as well as in magnetoelectric composites. Ni-rich Ni-Co spinel ferrite samples were processed by the ceramic method and bulk samples were sintered at $1350^{\circ} \mathrm{C}$ in the solid state and at $950{ }^{\circ} \mathrm{C}$ with $\mathrm{Bi}_{2} \mathrm{O}_{3}$ liquid phase. The sintered samples were characterized by light microscopy, scanning electron microscopy, Raman spectroscopy, vibrating sample magnetometry and capacitance dilatometry. With $\mathrm{Bi}_{2} \mathrm{O}_{3}$ additions as small as $0.6 \mathrm{~mol} \%$ it was possible to sinter the Ni-Co ferrite at $950^{\circ} \mathrm{C}$, obtaining high-density samples; however, such liquid-phase sintered samples presented iron oxide particles. The studied samples presented magnetoelastic sensitivities very close to $\mathrm{CoFe}_{2} \mathrm{O}_{4}$, with significantly lower magnetic hysteresis. The results thus indicate that the magnetic properties of the samples analyzed are suitable for applications in magnetomechanical sensors.
\end{abstract}

Keywords: ferrites, magnetoelastic sensors, magnetostriction, magnetic ceramics.

\section{Resumo}

Ferritas Ni-Co são cerâmicas magnetostritivas que possuem potencial de aplicação em sensores magnetostrictivos/ magnetoelásticos, bem como em compósitos magnetoelétricos. Ferritas espinélio do tipo Ni-Co com alto teor de Ni foram processadas por meio do método cerâmico e amostras foram sinterizadas no estado sólido a $1350{ }^{\circ} \mathrm{C}$ e via fase líquida a $950^{\circ} \mathrm{C}$ com adição de $\mathrm{Bi}_{2} \mathrm{O}_{3}$. As amostras sinterizadas foram caracterizadas por meio de microscopia óptica, microscopia eletrônica de varredura, espectroscopia Raman, magnetometria de amostra vibrante e dilatometria de capacitância. Utilizando-se pequenas adições de $\mathrm{Bi}_{2} \mathrm{O}_{3}$, na proporção de 0,6\% molar, foi possível sinterizar a ferrita $\mathrm{Ni}$-Co a $950^{\circ} \mathrm{C}$, obtendo-se amostras de alta densidade relativa; no entanto, estas amostras sinterizadas via fase líquida apresentaram partículas de óxido de ferro na microestrutura. As amostras produzidas apresentaram sensibilidade magnetoelástica próxima à da esperada para $\mathrm{CoFe}_{2} \mathrm{O}_{4}$, com histerese magnética significativamente menor. Os resultados obtidos indicam que as propriedades magnéticas das amostras analisadas são adequadas para aplicações em sensores magnetomecânicos.

Palavras-chave: ferritas, sensores magnetoelásticos, magnetostrição, cerâmicas magneticas.

\section{INTRODUCTION}

The magnetostrictive properties of materials and their magnetoelastic effects have been subject of study for applications in several types of sensors, such as the ones for sensing force, magnetic field, viscosity, density, fluid flow rate, elastic modulus of materials, humidity, gas, chem-bio agents in liquids, and blood coagulation [1].
Amorphous ferromagnetic alloys and iron/rare-earth alloys are frequently used in magnetostrictive/ magnetoelastic sensors. Ferrites with cobalt in their composition have been pointed out as alternative magnetostrictive materials for this application because of their lower cost and better corrosion resistance compared to iron-based alloys. However, the low mechanical resistance of these ceramic materials may be a disadvantage in some cases. The use cermets' 
technology to increase the mechanical strength of cobalt ferrite has been proposed [2], making it suitable for use in torque transducers. Nickel-based ferrites are ferrimagnetic ceramic materials. Their electromagnetic and magnetostrictive properties are suitable for applications in high-frequency devices [3], magnetic field sensors [4] and magnetoelectric transducers [5]. The substitution of $\mathrm{Ni}$ for $\mathrm{Co}$, as in $\mathrm{Ni}_{1-\mathrm{x}} \mathrm{Co}_{\mathrm{x}-}$ $\mathrm{Fe}_{2} \mathrm{O}_{4}$, is known to increase the saturation magnetization and magnetostriction magnitudes of these ferrites [6, 7]. The suitable magnetostrictive properties of these materials led Sedlar et al. [4] to study the performance of $\mathrm{Ni}$ and $\mathrm{Ni}-\mathrm{Co}$ ferrite in a magnetic field sensor and the best results were obtained for the Ni-Co ferrite. Ni-Co ferrite has also been pointed out as a material for use as anode material in lithium ion batteries [8].

Ferrite synthesis by means of chemical methods has made possible to obtain high-purity materials, with controlled particle size and morphology. There are many works about the synthesis of nanometric Ni-Co ferrites [9, 10]. These developments in the nanotechnology area are extremely important for these materials application advancement. On the other hand, the study of the traditional ceramic processing route is still important due to the suitability of large scale materials processing. Ferrites usually require sintering temperatures higher than $1200{ }^{\circ} \mathrm{C}$ but the possibility of sintering in temperatures lower than $1000{ }^{\circ} \mathrm{C}$ favors co-firing in electronic devices fabrication [11]. Until now, numerous processing methods have been proposed to reduce the required sintering temperatures to obtain ferrites with highest mass density. The use of additives such as $\mathrm{Bi}_{2} \mathrm{O}_{3}, \mathrm{~V}_{2} \mathrm{O}_{5}$ and copper substitutions are procedures that result in ferrites with high mass density using low sintering temperatures [12-14]. The presence of a liquid phase during sintering enhances diffusion and exerts capillary forces, favoring the densification at a lower sintering temperature compared to the temperature required for high densification without the liquid phase. The liquid-phase sintering of Ni-Co ferrites, using $5 \mathrm{wt} . \% \mathrm{Bi}_{2} \mathrm{O}_{3}$ as the sintering additive, has been studied [2]. The authors obtained samples with mass densities as high as $4.9 \mathrm{~g} / \mathrm{cm}^{3}$ with sintering at $950{ }^{\circ} \mathrm{C}$ for $2 \mathrm{~h}$ in air. However, there are very few works dealing with the effect of liquid-phase sintering on the magnetostriction of ferrites. This is important since the magnetostriction of ferrites is very sensitive to the microstructural changes that result from variations in both sintering and processing parameters [14, 15]. Also, it is known that secondary phases affect the magnetostrictive properties of ferrites $[16,17]$ and liquid-phase sintering generally introduces second phases in the microstructure of ceramics.

In this work, Ni-Co ferrite samples were liquid-phase sintered at low temperature and with small $\mathrm{Bi}_{2} \mathrm{O}_{3}$ additions (sintered at $950{ }^{\circ} \mathrm{C}$ with $0.6 \mathrm{~mol} \% \mathrm{Bi}_{2} \mathrm{O}_{3}$ ). The microstructure and the magnetic properties of the samples were compared to those obtained from samples sintered in the solid state at $1350{ }^{\circ} \mathrm{C}$, which is within the usual temperature range for solid-state ferrite sintering.

\section{EXPERIMENTAL PROCEDURE}

Two batches of Ni-Co ferrite were fabricated by the ce- ramic method with $67.99 \% \mathrm{Fe}_{2} \mathrm{O}_{3}, 28.63 \% \mathrm{NiO}$ and $3.38 \%$ $\mathrm{Co}_{3} \mathrm{O}_{4}$ oxides (wt.\%) raw materials. The oxides were dry mixed in an agate mortar and calcined at $850{ }^{\circ} \mathrm{C}$ for $4 \mathrm{~h}$. The $\mathrm{Ni}: \mathrm{Co}: \mathrm{Fe}$ proportion of each batch of calcined powder was estimated from the atomic absorption spectrometry analysis results. After calcinations the powders were wet milled with ethyl alcohol in an eccentric mill for $1 \mathrm{~h}$. For the fabrication of samples that were sintered with the liquid phase, $0.6 \mathrm{~mol} \%$ $\mathrm{Bi}_{2} \mathrm{O}_{3}$ was added to the calcined powder before the milling step. Pellets with $8 \mathrm{~mm}$ diameter and thickness 2-3 mm were uniaxially pressed at $50 \mathrm{MPa}$ and subsequently at $300 \mathrm{MPa}$ in an isostatic press.

The pellets were sintered at $1350{ }^{\circ} \mathrm{C}$ for $6 \mathrm{~h}$ (SSS) and the pellets with additives to obtain liquid-phase were sintered at $950{ }^{\circ} \mathrm{C}$ for $24 \mathrm{~h}$ (LPS). The densities of the sintered samples were evaluated by the Archimedes method. The crystal structures of the powders in calcined state and in a subsequently heat-treated one at $950^{\circ} \mathrm{C} / 24 \mathrm{~h}$ were evaluated by $\mathrm{X}$-ray diffraction $(\mathrm{XRD})$.

The microstructures of the sintered samples were evaluated in a scanning electron microscope (SEM) equipped with energy dispersive X-ray spectrometer. The samples were prepared by a sequence of grinding and polishing steps, followed by thermal etching.

The chemical homogeneity of the microstructures of both SSS and LPS samples was also evaluated by micro-Raman spectroscopy with an argon laser $(\lambda=514.5 \mathrm{~nm})$ of $8 \mathrm{~mW}$.

Magnetostriction measurements were carried out in samples cut from the sintered pellets. The dimensions of the samples were $3.977 \mathrm{~mm} \times 2.509 \mathrm{~mm} \times 2.421 \mathrm{~mm}(\mathrm{SSS})$ and $3.083 \mathrm{~mm} \times 2.364 \mathrm{~mm} \times 2.090 \mathrm{~mm}$ (LPS). The measurement method was capacitance dilatometry, described in detail elsewhere [18]. Magnetization measurements were performed in the same cut samples by vibrating-sample magnetometry (VSM). Magnetostriction was measured in parallel and perpendicular directions to the applied field.

\section{RESULTS AND DISCUSSION}

The results of the AAS quantitative analysis of the calcined powders are shown on Table I. The batches presented similar Co content but the SSS batch presented a higher Fe:Ni ratio.

Table I - Results of AAS analysis (wt.\%) of each element in the calcined powders and calculated $\mathrm{Ni}: \mathrm{Co}: \mathrm{Fe}$ atomic proportions.

[Tabela I - Resultados da análise por espectrometria de absorção atômica (percentual em peso) para cada elemento previsto nos pós calcinados e proporções atômicas $\mathrm{Ni}$ :Co:Fe calculadas.]

\begin{tabular}{ccccc}
\hline Element & $\mathrm{Fe}$ & $\mathrm{Ni}$ & $\mathrm{Co}$ & $\mathrm{Ni}: \mathrm{Co}: \mathrm{Fe}$ \\
\hline $\begin{array}{c}\text { Batch } \\
\text { for LPS }\end{array}$ & $47.1 \pm 0.8$ & $21.4 \pm 0.4$ & $3.04 \pm 0.20$ & $0.90: 0.13: 1.97$ \\
$\begin{array}{c}\text { Batch } \\
\text { for SSS }\end{array}$ & $48.0 \pm 2.1$ & $18.5 \pm 1.0$ & $3.32 \pm 0.08$ & $0.80: 0.14: 2.06$ \\
\hline
\end{tabular}




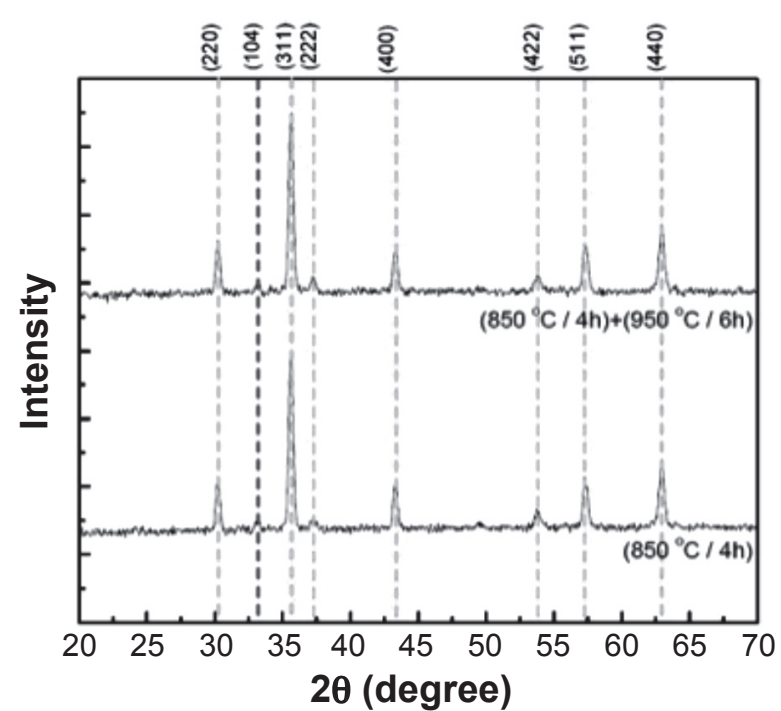

Figure 1: X-ray diffraction patterns of powders from the SSS batch. The red line indicates the peak that corresponds to the (104) plane of hematite (JCPDS file 89-0599) and the green lines indicate the typical peaks of the spinel phase.

[Figura 1: Difratogramas de raios $X$ dos pós calcinados utilizados nas amostras sinterizadas no estado sólido. A linha vermelha indica o pico correspondente ao plano (104) da hematita (JCPDS 89.0599) e as linhas verdes indicam os picos típicos da fase espinélio.]

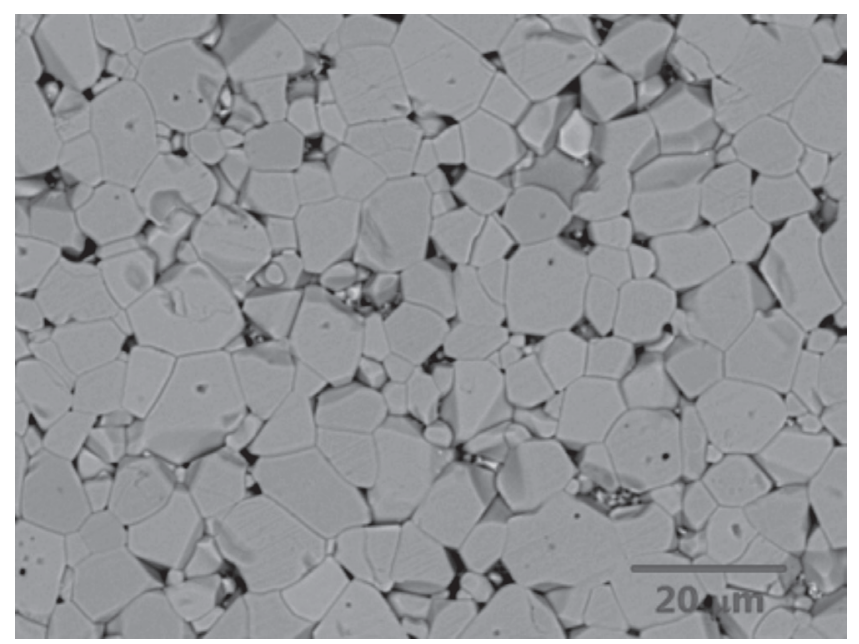

Figure 2: SEM image of the SSS sample.

[Figura 2: Imagem obtida em microscópio eletrônico de varredura da amostra sinterizada no estado sólido.]

The X-ray diffraction patterns of the SSS batch after calcination and calcination followed by heat treatment are shown on Fig. 1. The peak expected for the (104) plane of hematite $\left(\alpha-\mathrm{Fe}_{2} \mathrm{O}_{3}\right.$-rhombohedral) was detected in both powders, indicating that the reactions in solid state to form the spinel phase were not complete [19]. The calculated lattice parameters of the spinel phases were $8.343 \AA$ for the calcined powder and $8.331 \AA$ for the powder that was subsequently heat treated.

The densities measured were $4.90 \mathrm{~g} / \mathrm{cm}^{3}$ for the SSS sample and $5.02 \mathrm{~g} / \mathrm{cm}^{3}$ for the LPS sample; LPS thus increased the density of the material, with a sintering temperature $400{ }^{\circ} \mathrm{C}$ lower.

Figs. 2 and 3 show SEM images of the microstructures

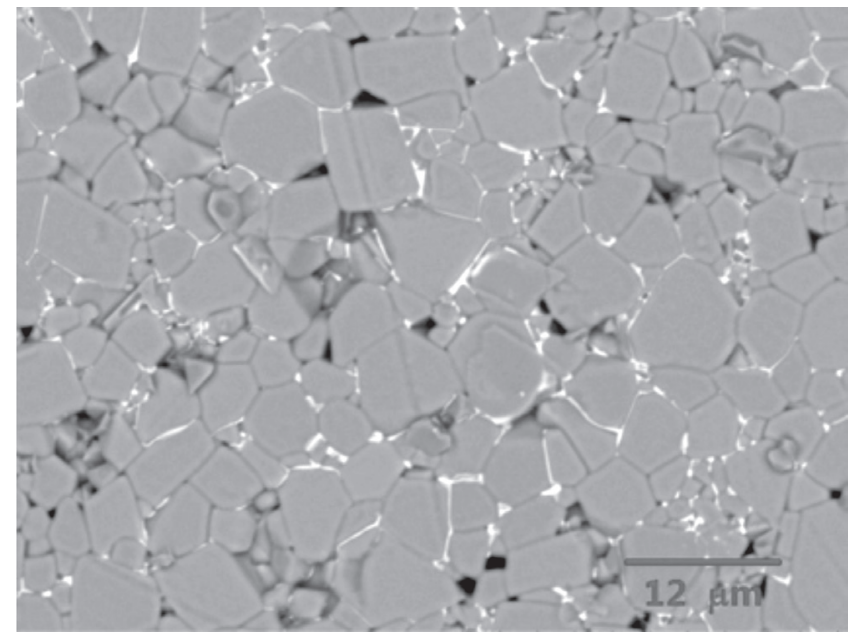

Figure 3: SEM image of the LPS sample.

[Figura 3: Imagem obtida em microscópio eletrônico de varredura da amostra sinterizada via fase líquida.]

of the SSS and LPS samples; the average grain sizes, estimated from these figures by a linear intercept method [20] were $3 \mu \mathrm{m}$ for the LPS sample and $5 \mu \mathrm{m}$ for the SSS sample. The LPS process resulted in a microstructure with pore-free grains, with porosity located at grain boundaries; the crystallized liquid phase appears as films and particles located at grain boundaries. The grain size of the SSS sample is fairly uniform and the intragranular porosity is very small: the porosity of the sample is predominantly intergranular.

The EDX spectrum shown in Fig. 4 was taken from a white intergrain particle observed in the LPS sample in Fig. 3. This result suggests that this phase, rich in bismuth, has a high concentration of the $\mathrm{Bi}_{2} \mathrm{O}_{3}$ additive, as well as small amounts of impurities coming from the raw materials. However, due to the small thickness of these intergrain phases, much lower than $5 \mu \mathrm{m}$, which is the electron beam average size in SEM, there is the influence of the ferrite background on the measurement that do not allow to obtain a measurement only of the isolated intergrain phase.

The EDX analysis in the centers of the ferrite grains of the LPS sample revealed two composition types: a major

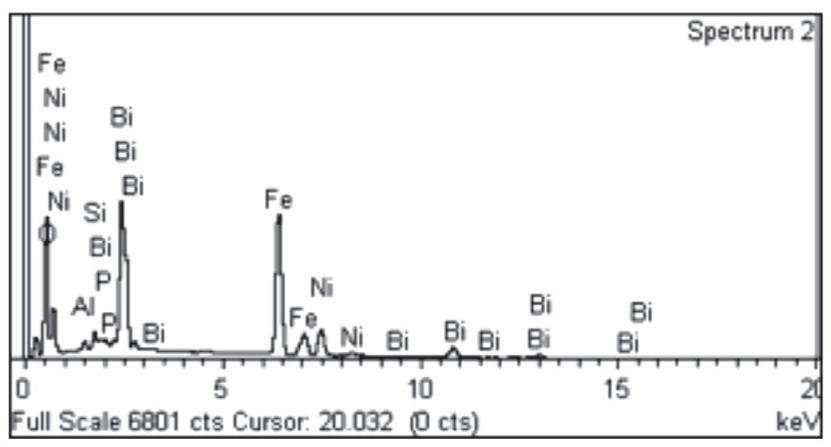

Figure 4: Results of EDX analysis of one of the white particles observed in Fig. 3.

[Figura 4: Resultados da análise por EDX de uma das partículas brancas observadas na Fig. 3.] 
Fe-Co-Ni-O one and a cobalt-free one. Table II presents the typical composition of both phases. The $(\mathrm{Ni}+\mathrm{Fe})$ : O proportion of the Co-free grains is near 2:3, as in $\mathrm{Fe}_{2} \mathrm{O}_{3}$, and $\mathrm{Ni}_{2} \mathrm{O}_{3}$. These results thus indicate that the $\mathrm{Co}$-free grains are probably mainly constituted of $\mathrm{Fe}_{2} \mathrm{O}_{3}$.

Table III shows the results of the EDX analysis of the SSS sample, indicating the average and the standard deviation of the results obtained in the center of five grains. The results of the semi-quantitative analysis shown on Tabs. II and III indicated a $\mathrm{Ni}: \mathrm{Co}: \mathrm{Fe}$ approximate atomic proportion of

Table II - Composition obtained from EDX analyses of the grains from the microstructure of the LPS sample (at.\%).

[Tabela II - Composição obtida por EDX (percentual atômico) de grãos da microestrutura da amostra sinterizada via fase líquida.]

\begin{tabular}{ccc}
\hline Element & Ni-Co spinel grain & Co-free grain \\
\hline $\mathrm{Ni}$ & 11.91 & 3.76 \\
$\mathrm{Co}$ & 1.76 & 0.00 \\
$\mathrm{Fe}$ & 30.79 & 34.75 \\
$\mathrm{O}$ & 55.54 & 61.47 \\
$\mathrm{Bi}$ & 0.00 & 0.01 \\
$\mathrm{Ni}: \mathrm{Co}: \mathrm{Fe}$ & $0.80: 0.12: 2.08$ & $0.29: 0.00: 2.71$ \\
\hline
\end{tabular}

Table III - Results from the EDX analysis of the SSS sample (at.\%).

[Tabela III - Resultados (em percentual atômico) da análise de EDX da amostra sinterizada no estado sólido.]

\begin{tabular}{lcccc}
\hline Element & $\mathrm{Ni}$ & $\mathrm{Co}$ & $\mathrm{Fe}$ & $\mathrm{O}$ \\
\hline Average & 9.254 & 1.694 & 24.123 & 64.929 \\
Std. deviation & 0.251 & 0.108 & 0.369 & 0.494 \\
\hline
\end{tabular}

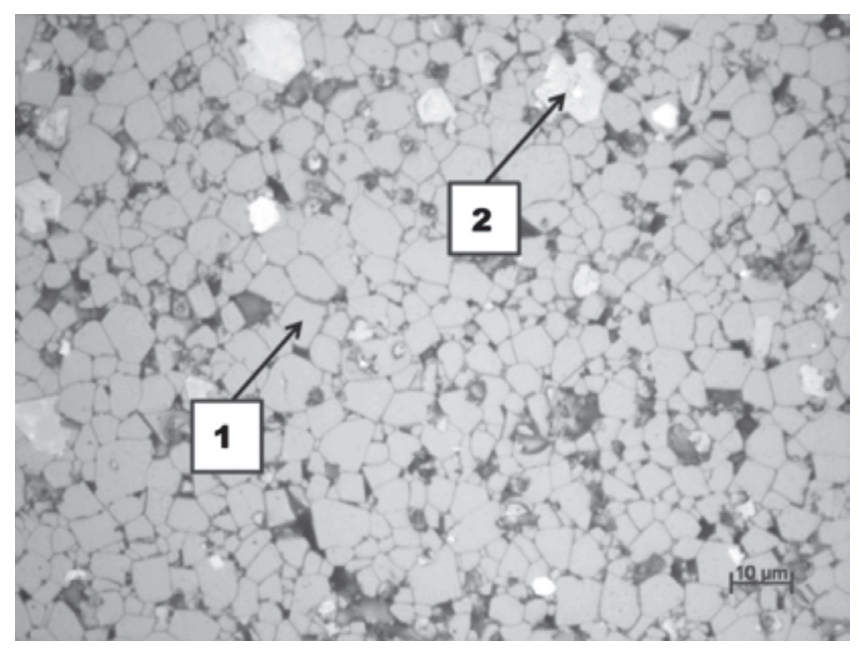

Figure 5: Optical microscopy image of the LPS sample's microstructure. The arrows indicate the two types of grains from which the Raman spectra were taken: phase 1 , grey grains; phase 2 , white grains.

[Figura 5: Imagem obtida por microscopia óptica da microestrutura da amostra sinterizada via fase líquida. As setas indicam os dois tipos de grãos nos quais foi realizada a análise por espectroscopia Raman: fase 1, grãos cinza; fase 2, grãos brancos.]

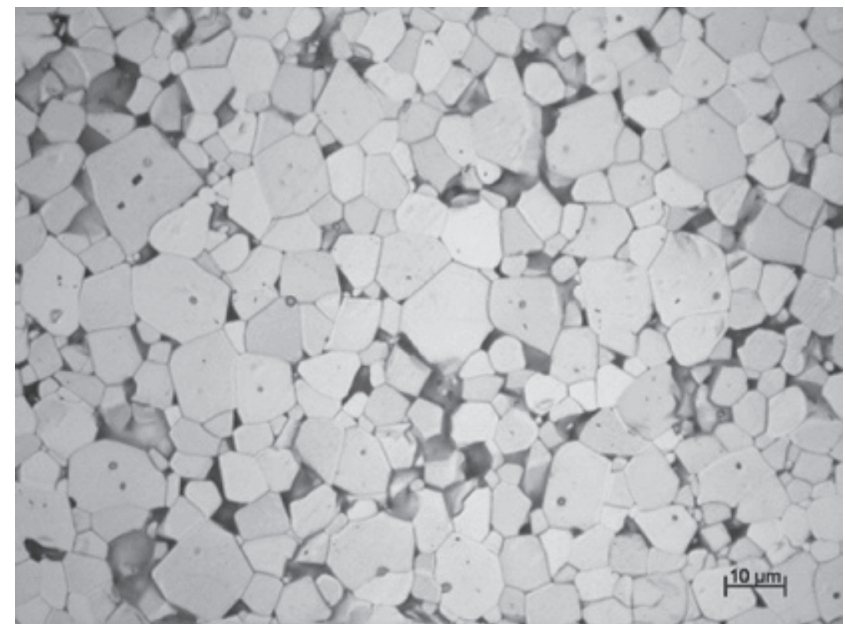

Figure 6: Optical microscopy image of the SSS sample's microstructure.

[Figura 6: Imagem, obtida por microscopia óptica, da microestrutura da amostra sinterizada no estado sólido.]

0.8:0.1:2.1 for the spinel Ni-Co phase in both SSS and LPS samples.

Figs. 5 and 6 show light microscopy images of the sintered samples. It was observed that the LPS sample's microstructure was constituted of few and sparsely distributed white grains surrounded by a major phase, constituted of grey grains. The presence of such white phase was not observed in the SSS sample. The Raman spectra of the LPS sample were taken from three grains of each type.

Figs. 7 to 9 show Raman spectra of the LPS and SSS samples, taken from the centers of selected grains.

The spectra of Figs. 7 and 8, for SSS and LPS samples, presented essentially the same pattern, which is typical of spinel Ni ferrites $[21,22]$. In the case of the spectra of Fig.

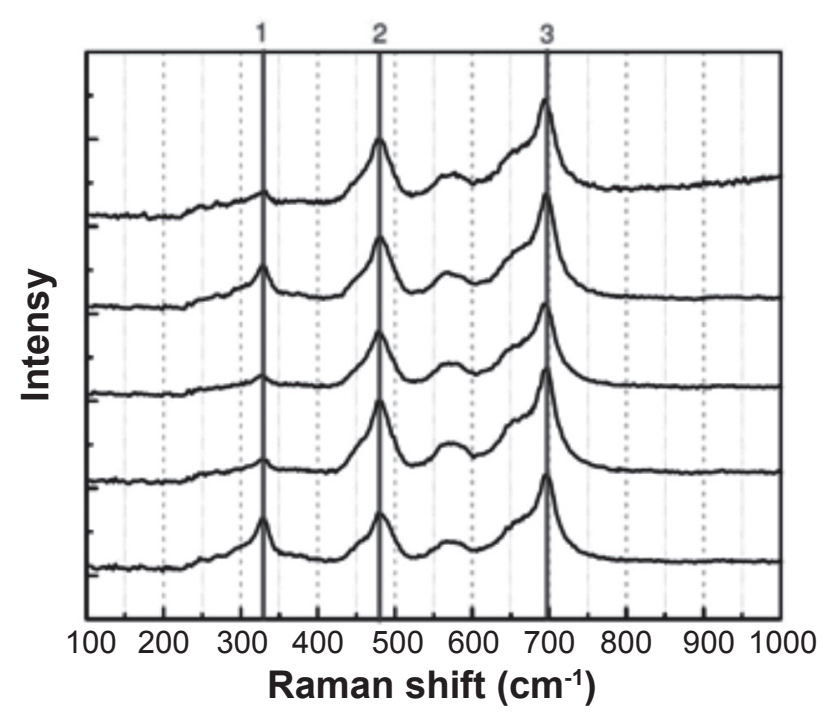

Figure 7: Raman spectra of the SSS sample. The sharper peaks are marked in red.

[Figura 7: Espectros Raman obtidos na amostra sinterizada no estado sólido. Os picos mais agudos estão marcados em vermelho.] 


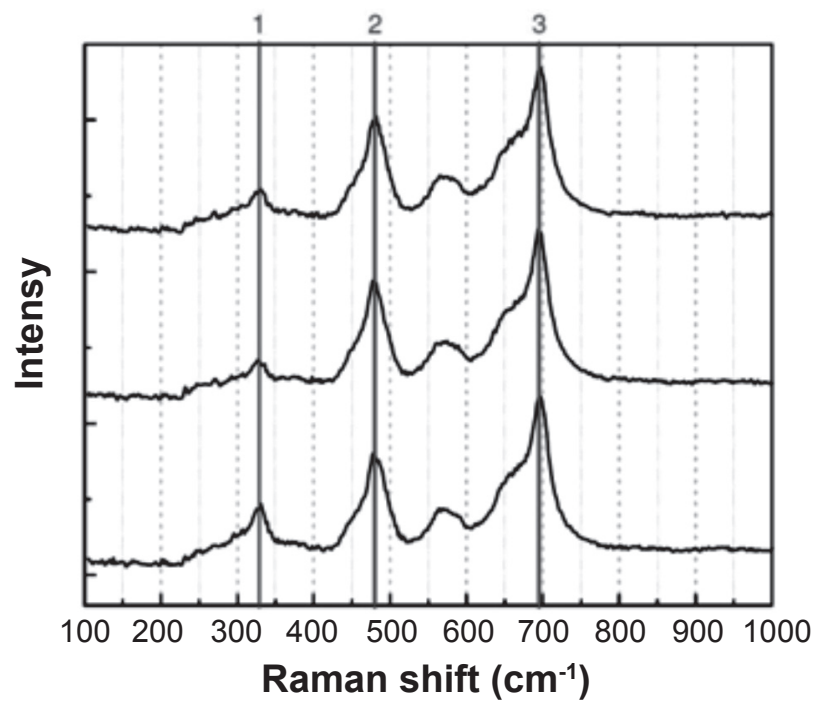

Figure 8: Raman spectra of the grey grains observed in the LPS sample. The sharper peaks are marked in red.

[Figura 8: Espectros Raman dos grãos cinza observados na amostra sinterizada via fase líquida. Os picos mais agudos estão numerados.]

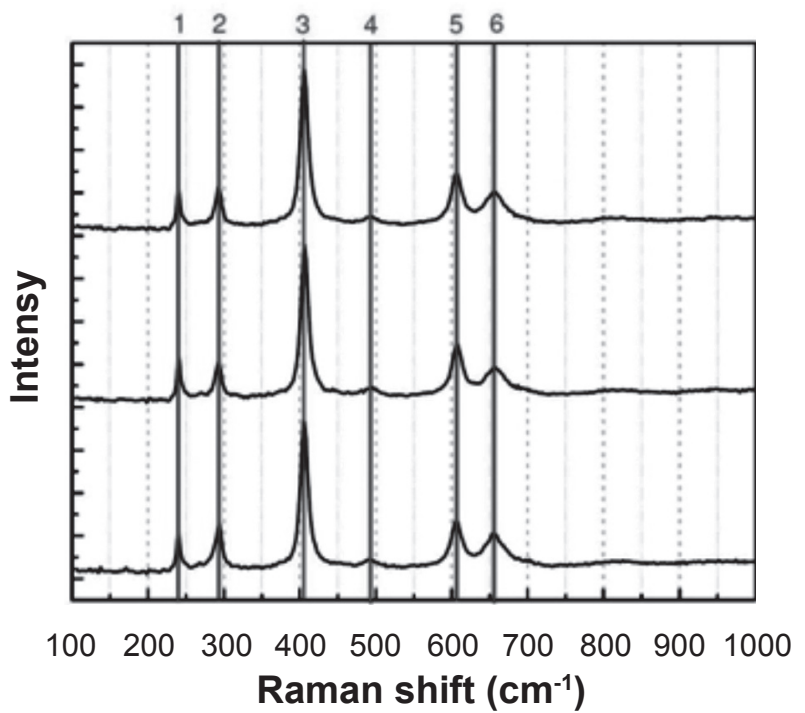

Figure 9: Raman spectra of the white grains observed in the LPS sample. The sharper peaks are numbered.

[Figura 9: Espectros Raman dos grãos brancos observados na amostra sinterizada via fase líquida. Os picos mais agudos estão numerados.]

9 , taken from the white phases observed in optical microscope of the LPS sample (Fig. 5), the peaks numbered 1 to 5 match well with the phase $\alpha-\mathrm{Fe}_{2} \mathrm{O}_{3}$ (hematite) $[23,24]$. However, the peak number 6 has an average value of 655 $\mathrm{cm}^{-1}$ of the Raman shift, which is close to the range of $663-$ $706 \mathrm{~cm}^{-1}$ range that is known to be the strongest mode of $\mathrm{Fe}_{3} \mathrm{O}_{4}$ (magnetite) [25]. In addition, no spinel ferrite peak vestiges were observed in those white grains. These results thus indicate that the white grains are constituted of iron oxide, corroborating the previous chemical analyses, XRD and EDX experiments.

Figs. 10a-b and 11 show the results from the magnetization measurements of the sintered samples. The parameters obtained from such data are shown on Table IV. The satura-
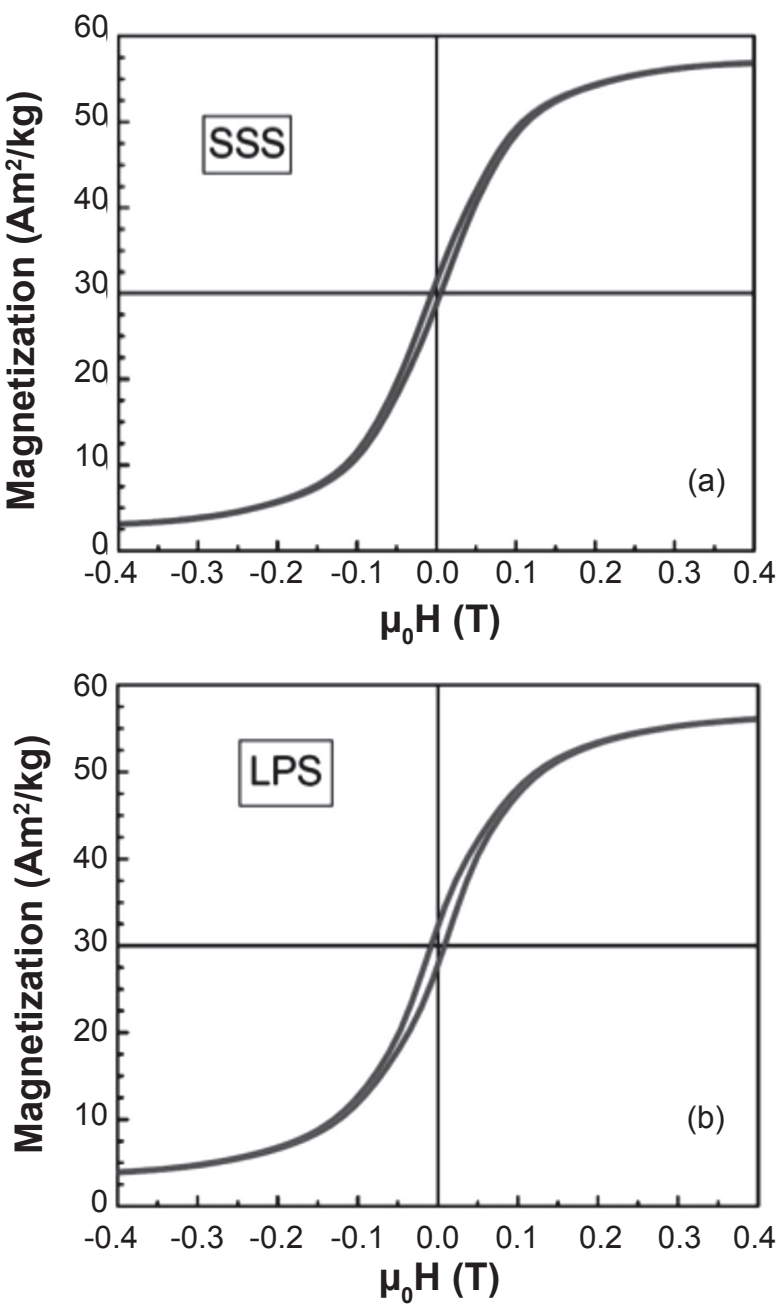

Figure 10: (a) Hysteresis curve of the LPS sample; (b). Hysteresis curve of the SSS sample.

[Figura 10: (a) Curva de histerese magnética da amostra sinterizada via fase líquida (a) e sinterizada no estado sólido (b).]

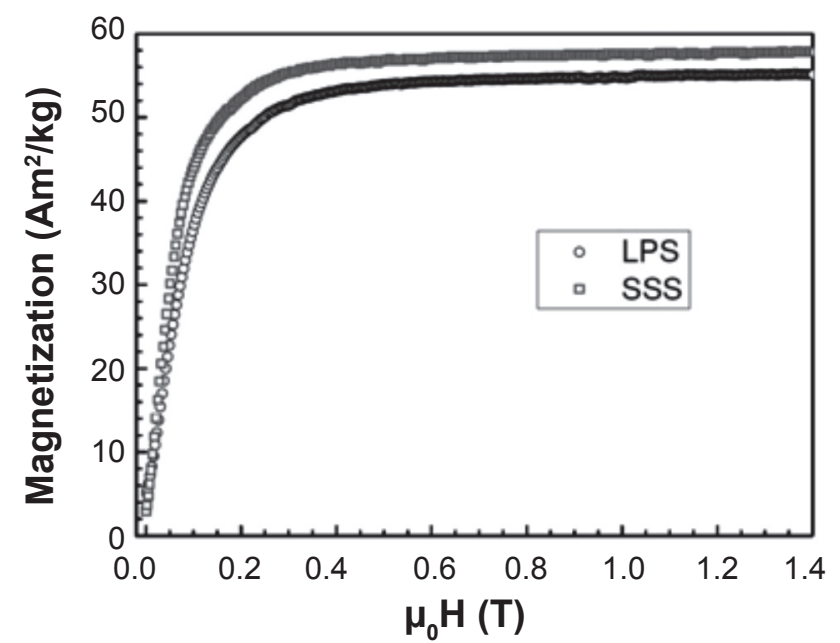

Figure 11: Initial magnetization curves.

[Figura 11: Curvas de magnetização inicial.]

tion magnetization values of both samples were similar and the slightly higher coercivity of the LPS sample may be attributed to: the smaller grains (higher grain boundary area) 
Table IV - Results obtained from the magnetization measurements.

[Tabela IV - Resultados obtidos das medidas de magnetização.]

\begin{tabular}{lcc}
\hline Sample: & $\mathrm{SSS}$ & $\mathrm{LPS}$ \\
\hline Saturation magnetization $-\mathrm{M}_{\mathrm{S}}\left(\mathrm{A} . \mathrm{m}^{2} / \mathrm{kg}\right)$ & 56 & 53 \\
Coercivity $-\mu_{0} \mathrm{H}_{\mathrm{C}}(\mathrm{mT})$ & 5.4 & 8.6 \\
Remanence $-\mathrm{M}_{\mathrm{R}}\left(\mathrm{A} . \mathrm{m}^{2} / \mathrm{kg}\right)$ & 2.8 & 4.5 \\
$\mathrm{M}_{\mathrm{R}} / \mathrm{M}_{\mathrm{s}}$ & 0.050 & 0.162 \\
\hline
\end{tabular}

of the sample, increasing the pinning effect on the magnetic domains' walls; the presence of non-magnetic second phase particles, such as diamagnetic $\alpha-\mathrm{Bi}_{2} \mathrm{O}_{3}$ and antiferromagnetic $\alpha-\mathrm{Fe}_{2} \mathrm{O}_{3}$. This factor may have also contributed to the slightly lower saturation magnetization of this sample.

The $\mathrm{M}_{\mathrm{s}}$ values reported by other authors for $\mathrm{Ni}_{\mathrm{x}} \mathrm{Co}_{1-\mathrm{x}-}$ $\mathrm{Fe}_{2} \mathrm{O}_{4}$ vary within a wide range, depending on the fabrication route. For example, $\mathrm{Ni}_{0.5} \mathrm{Co}_{0.5} \mathrm{Fe}_{2} \mathrm{O}_{4}$ has benn obtained by means of mechanical alloying and their samples presented a large variation of $\mathrm{M}_{\mathrm{s}}$, as a function of the annealing temperature after milling [26]. Additionally, Table $\mathrm{V}$ shows $\mathrm{M}_{\mathrm{s}}$ values of chemically synthesized $\mathrm{Ni}_{\mathrm{x}} \mathrm{Co}_{1-\mathrm{x}} \mathrm{Fe}_{2} \mathrm{O}_{4}$ ferrites from different sources $[6,7,10,27,28]$; all these works show a tendency of $M_{s}$ increasing values with the raise of cobalt content. In Fig. 12, a plot of $\mathrm{M}_{\mathrm{s}}$ as a function of $\mathrm{Ni}$ content " $\mathrm{x}$ " in $\mathrm{Ni}_{\mathrm{x}} \mathrm{Co}_{1-\mathrm{x}} \mathrm{Fe}_{2} \mathrm{O}_{4}$, elaborated with the data presented on Tab. V, shows clearly that the $\mathrm{M}_{\mathrm{s}}$ values obtained in the present work (dashed line) approach the average of pure cobalt ferrite and are within the range reported for $\mathrm{Ni}_{\mathrm{x}} \mathrm{Co}_{1-\mathrm{x}} \mathrm{Fe}_{2} \mathrm{O}_{4}$ with $\mathrm{x} \leq 0.5$. The slight iron excess of the ferrite, as verified in the EDX analysis, probably contributed to this result.

According to Fig. 13, the trends reported in literature for

Table V - Saturation magnetization values [A.m² $/ \mathrm{kg}$ ] of chemically synthesized $\mathrm{Ni}_{\mathrm{x}} \mathrm{Co}_{1-\mathrm{x}} \mathrm{Fe}_{2} \mathrm{O}_{4}$ reported by different authors. The data have been approximated to integers.

[Tabela V - Valores de magnetização de saturação [A.m²] $\mathrm{kg}]$ reportados por diferentes autores para amostras de $\mathrm{Ni}_{x} \mathrm{Co}_{1-\mathrm{F}} \mathrm{Fe}_{2} \mathrm{O}_{4}$ sintetizadas por meio químico. Os dados foram aproximados para números inteiros.]

\begin{tabular}{cccccc}
\hline $\mathrm{x}$ & Ref.[27] & Ref.[7] & Ref.[28] & Ref.[10] & Ref.[6] \\
\hline 0 & 66 & 37 & 70 & 56 & - \\
0.1 & 65 & - & 69 & - & - \\
0.2 & 58 & 37 & 65 & 50 & - \\
0.3 & - & - & 63 & - & - \\
0.4 & - & 45 & 60 & 47 & - \\
0.5 & 35 & - & 57 & - & 54 \\
0.6 & 29 & 34 & 55 & 42 & 47 \\
0.7 & - & - & 52 & - & 42 \\
0.8 & 15 & 27 & 51 & 36 & 40 \\
0.9 & - & - & 47 & - & 25 \\
1.0 & 14 & 13 & 45 & 30 & 12 \\
\hline
\end{tabular}

the $\mathrm{M}_{\mathrm{R}} / \mathrm{M}_{\mathrm{s}}$ ratio as a function of " $\mathrm{x}$ " in $\mathrm{Ni}_{\mathrm{x}} \mathrm{Co}_{1-\mathrm{x}} \mathrm{Fe}_{2} \mathrm{O}_{4}$ vary considerably. The $\mathrm{M}_{\mathrm{R}} / \mathrm{M}_{\mathrm{s}}$ ratios of both LPS and SSS samples may be considered low when compared to the literature data. Also, in $\mathrm{CoFe}_{2} \mathrm{O}_{4}$ LPS samples previously studied [14], the $\mathrm{M}_{\mathrm{R}} / \mathrm{M}_{\mathrm{s}}$ ratios ranged from 0.197 to 0.420 , which is larger than the values obtained for the Ni-Co ferrite samples. The ferrites produced in this work thus have low magnetic hysteresis and high saturation magnetization when compared to most Ni-Co ferrites presented in literature. These features make them interesting materials for sensors applications.

Figs. 14-15 show the magnetostriction curves of the sintered samples and Table VI shows some parameters extracted from these curves.

Fig. 16 shows the magnetoelastic sensitivity (S) curves, calculated by differentiating the magnetostriction curves,

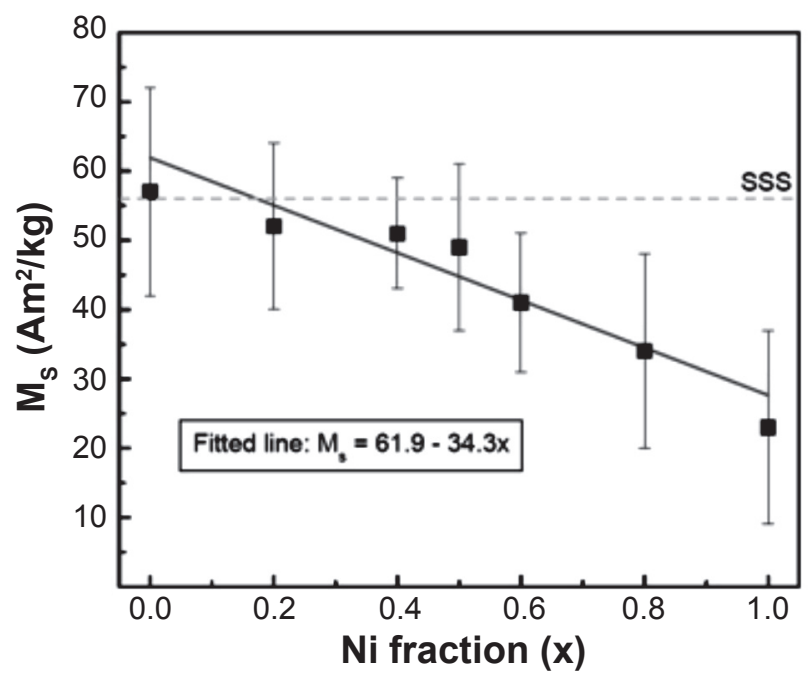

Figure 12: Graphical representation of the $\mathrm{M}_{\mathrm{s}}$ values reported in literature for $\mathrm{Ni}_{x} \mathrm{Co}_{1-\mathrm{x}} \mathrm{Fe}_{2} \mathrm{O}_{4}$. The dashed line indicates the $\mathrm{M}_{\mathrm{s}}$ obtained in this work for the SSS sample.

[Figura 12: Representação gráfica dos valores de $M_{\mathrm{s}}$ reportados na

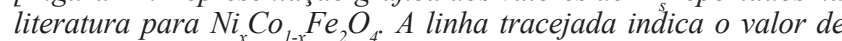
$M_{s}$ da amostra sinterizada no estado sólido obtida neste trabalho.]

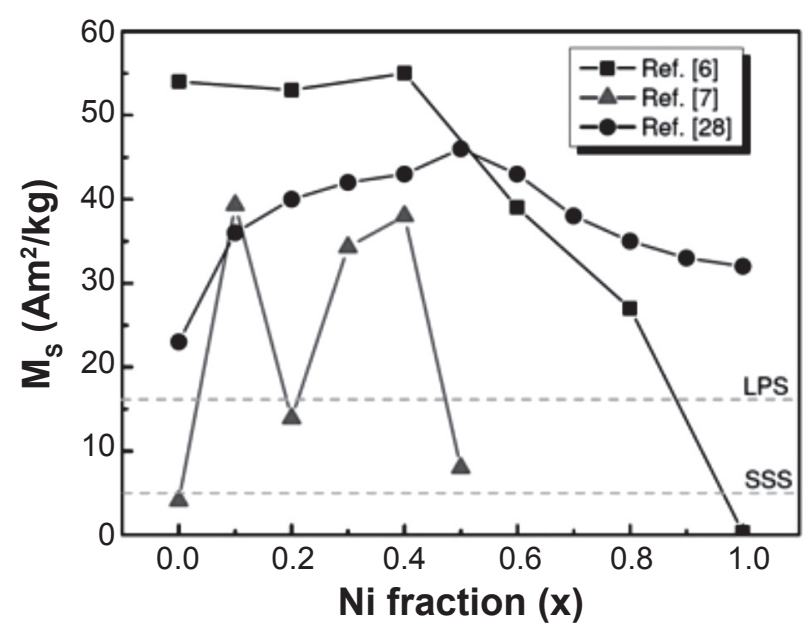

Figure 13: Values reported for $\mathrm{M}_{\mathrm{R}} / \mathrm{M}_{\mathrm{s}}$ parameter of $\mathrm{Ni}_{\mathrm{x}} \mathrm{Co}_{1-\mathrm{x}} \mathrm{Fe}_{2} \mathrm{O}_{4}$. [Figura 13: Valores do parâmetro $M_{R} / M_{s}$ reportados para $\left.\mathrm{Ni}_{x} \mathrm{Co}_{1-x} \mathrm{Fe}_{2} \mathrm{O}_{4} \cdot\right]$ 


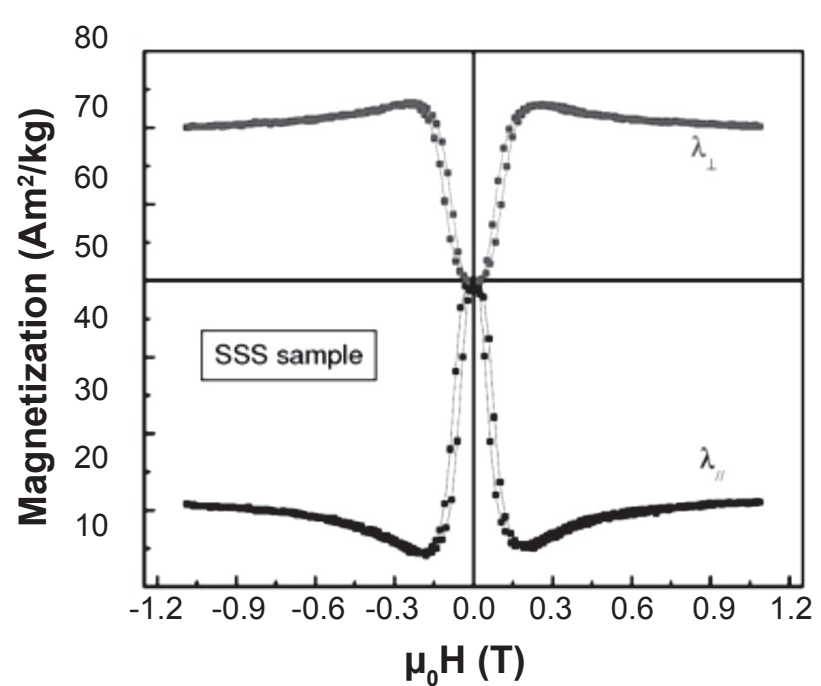

Figure 14: Magnetostriction curves of the SSS sample: parallel $\left(\lambda_{/ /}\right)$ and perpendicular $\left(\lambda_{1}\right)$ to the magnetic field.

[Figura 14: Curvas de magnetostricção da amostra sinterizada no estado sólido: direção paralela $\left(\lambda_{\text {, }}\right)$ e perpendicular $\left(\lambda_{\perp}\right)$ ao campo magnético.]

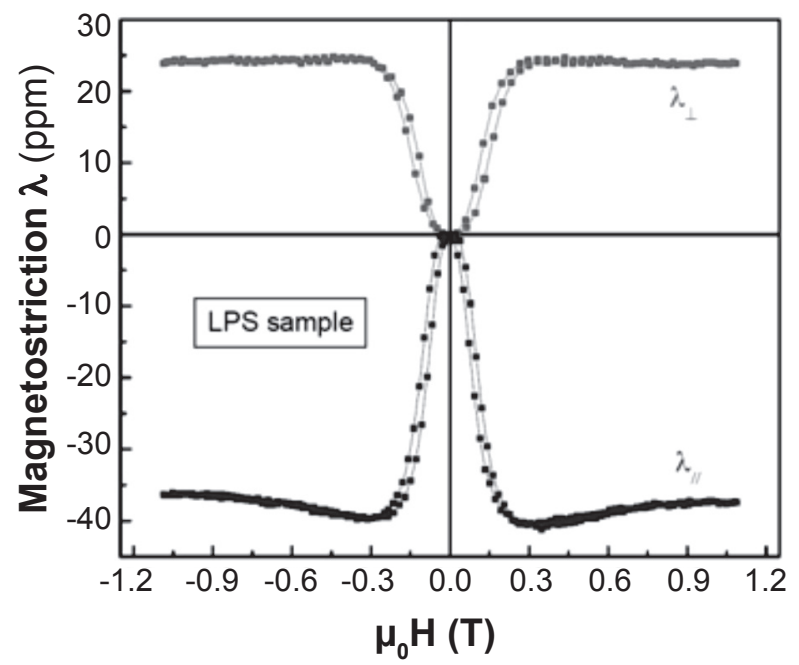

Figure 15: Magnetostriction curves of the LPS sample: parallel $\left(\lambda_{\mu}\right)$ and perpendicular $\left(\lambda_{1}\right)$ to the magnetic field.

[Figura 15: Curvas de magnetostricção da amostra sinterizada via fase líquida: direção paralela $\left(\lambda_{/}\right)$e perpendicular $\left(\lambda_{\perp}\right)$ ao campo magnético.]

Table VI - Saturation magnetostrictions and saturation fields obtained from Figs. 14-15.

[Tabela VI - Valores de magnetostricção de saturação e campos magnéticos de saturação, obtidos das Figs. 14-15.]

\begin{tabular}{cccc}
\hline Sample & $\left(\lambda_{/ /}\right)_{\mathrm{s}}$ & $\left(\lambda_{\perp}\right)_{\mathrm{s}}$ & $\begin{array}{c}\mu_{0} \mathrm{H} \text { at } \\
\text { saturation }\end{array}$ \\
\hline SSS & $-35 \mathrm{ppm}$ & $23 \mathrm{ppm}$ & $0.287 \mathrm{~T}$ \\
LPS & $-40 \mathrm{ppm}$ & $24 \mathrm{ppm}$ & $0.353 \mathrm{~T}$ \\
\hline
\end{tabular}

and Tables VII and VIII show the moduli of the maximum magnetoelastic sensitivities observed. The LPS sample presented the lowest magnetoelastic sensitivity at low fields, but it is the most sensitive sample for $\mu_{0} \mathrm{H}$ between 0.10 -

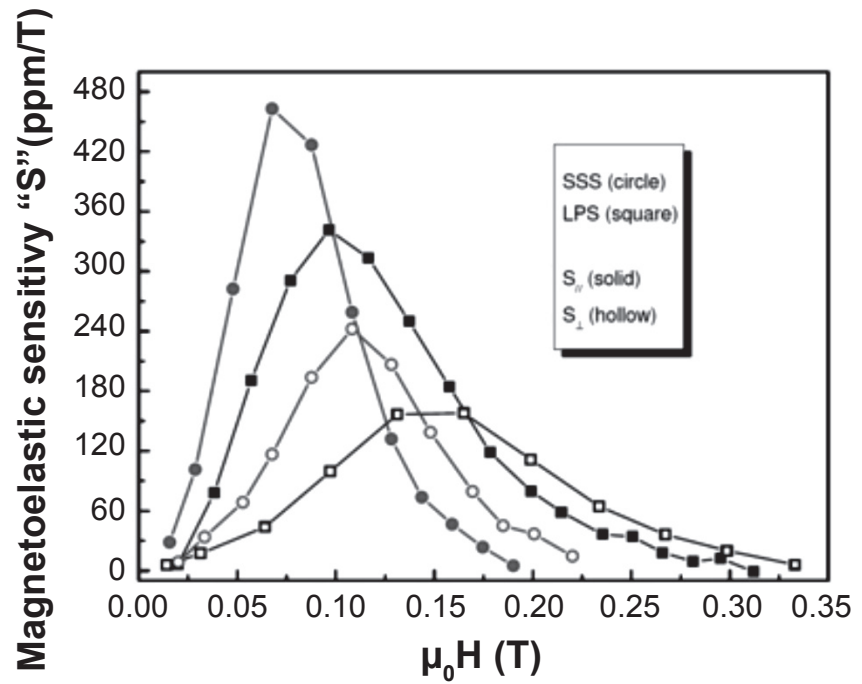

Figure 16: Modulus of the magnetoelastic sensitivities of the sintered samples.

[Figura 16: Módulo da sensibilidade magnetoelástica das amostras sinterizadas.]

Table VII - Maximum magnetoelastic sensitivities $\left(\mathrm{S}_{\mathrm{m}}\right)_{/ /}$and corresponding $\mu_{0} \mathrm{H}$ values.

[Tabela VII - Sensibilidades magnetoelásticas máximas $\left(S_{m}\right)$, e valores de $\mu_{0} H$ correspondentes.]

\begin{tabular}{ccc}
\hline Sample & $\begin{array}{c}\left(\mathrm{S}_{\mathrm{m}}\right)_{/ /} \\
{[\mathrm{ppm} / \mathrm{T}]}\end{array}$ & $\begin{array}{c}\mu_{0} \mathrm{H} \\
{[\mathrm{T}]}\end{array}$ \\
\hline LPS & 341 & 0.096 \\
SSS & 463 & 0.068 \\
\hline
\end{tabular}

Table VIII - Maximum magnetoelastic sensitivities $\left(\mathrm{S}_{\mathrm{m}}\right)_{\perp}$ and corresponding $\mu_{0} \mathrm{H}$ values.

[Tabela VIII - Sensibilidades magnetoelásticas máximas $\left(S_{m}\right)_{\perp}$ e valores de $\mu_{0} H$ correspondentes.]

\begin{tabular}{ccc}
\hline Sample & $\begin{array}{c}\left(\mathrm{S}_{\mathrm{m}}\right)_{\perp} \\
{[\mathrm{ppm} / \mathrm{T}]}\end{array}$ & $\begin{array}{c}\mu_{0} \mathrm{H} \\
{[\mathrm{T}]}\end{array}$ \\
\hline LPS & 158 & 0.165 \\
SSS & 242 & 0.108 \\
\hline
\end{tabular}

$0.17 \mathrm{~T}$, approximately. It is important to mention that the derivative of both magnetostriction and magnetization curves are affected by the samples' geometry and dimensions, but the dimensions of both samples evaluated here are similar enough to allow a qualitative comparison between their magnetoelastic sensitivities.

The excess iron detected in the EDX analysis may have different effects on the magnetic properties of the ferrite. For example, the saturation magnetization of the ferrite may be increased when the excess iron forms magnetite $\left(\mathrm{Fe}_{3} \mathrm{O}_{4}\right)$, because this phase has a relatively high saturation magnetization (around $90 \mathrm{~A} . \mathrm{m}^{2} / \mathrm{kg}$ [29]). Moreover, Ni-Co ferrite and magnetite magnetostrictions have opposite signs in the direction parallel to the magnetic field, namely, Ni-Co fer- 
rite retracts and magnetite expands. Therefore, the absolute value of the ferrite magnetostriction would be smaller due to the competition with the magnetite.

Comparing the results from this work with the ones obtained in $\mathrm{CoFe}_{2} \mathrm{O}_{4}$ tested under similar conditions [14], one can observe that the Ni-Co ferrite presented similar maximum magnetoelastic sensitivity values, but occurring at considerably lower fields. The $\left(\mathrm{S}_{\mathrm{m}}\right)_{/ /}$values of the $\mathrm{CoFe}_{2} \mathrm{O}_{4}$ samples in [14] varied from 366 to $541 \mathrm{ppm} / \mathrm{T}$ and the minimum corresponding $\mu_{0} \mathrm{H}$ found was $0.19 \mathrm{~T}$. These results suggest that the Ni-rich Ni-Co ferrite here studied may be more sensitive than $\mathrm{CoFe}_{2} \mathrm{O}_{4}$ at low magnetic fields. When associated to a piezoelectric material, forming a magnetoelectric composite $[5,30]$, the good electromagnetic [3] and magnetostrictive properties of Ni-Co ferrites make them candidates for applications in high-frequency tunable devices, for example.

\section{CONCLUSIONS}

The Ni-rich Ni-Co spinel ferrite samples presented magnetoelastic sensitivities very close to that of $\mathrm{CoFe}_{2} \mathrm{O}_{4}$, with significantly lower magnetic hysteresis than that ferrite. The $M_{R} / M_{s}$ ratios were lower than the values reported in literature for $\mathrm{Ni}_{\mathrm{x}} \mathrm{Co}_{1-\mathrm{x}} \mathrm{Fe}_{2} \mathrm{O}_{4}$ ferrites. Liquid-phase sintering with $\mathrm{Bi}_{2} \mathrm{O}_{3}$ slightly increased the magnetic hysteresis and had little effect on the magnetostriction values; however, the magnetoelastic sensitivity of the liquid-phase sintered sample was lower than that obtained in the solid-state sintered sample. Liquid-phase sintering at $950{ }^{\circ} \mathrm{C}$ for $24 \mathrm{~h}$ resulted in chemically heterogeneous samples, with the presence of iron oxides. Because of its relatively high magnetoelastic sensitivity and low magnetic hysteresis, the ferrite is a candidate for application in magnetoelastic sensors and magnetoelectric composites.

\section{ACKNOWLEDGMENTS}

The authors acknowledge the support given by the following people/institutions: the Brazilian agencies FAPESP (Procs. 2009/09524-7, 2012/01448-2 and 2011/21258-0), CNPq (504282/2010-7) and CAPES for the financial support; students M. S. Hieda (Instituto Tecnológico de Aeronáutica, Brazil) and M. B. S. Dias (University of S. Paulo, Brazil) for obtaining the microstructure images; Materials Division of the Institute for Aeronautics and Space, Brazil, for the chemical and SEM analysis.

\section{REFERENCES}

[1] C. A. Grimes, S. C. Roy, S. Rani, Q. Cai, Sensors 11 (2011) 2809-2844.

[2] Y. Chen, J. E. Snyder, C. R. Schwichtenberg, K. W. Dennis, R. W. McCallum, D. C. Jiles, IEEE Trans. Magn. 35, 5 (1999) 3652-3654.

[3] K. C. Chan, X. T. Liew, L. B. Kong, Z. W. Li, G. Q. Lin, J. Amer. Cer. Soc. 91, 12 (2008) 3937-3942.
[4] M. Sedlar, V. Matejec, I. Paulicka, Sensor. Actuat. A 84 (2000) 297-302.

[5] J. Chen, Z. Xu, X. Lu, Ferroelectrics 410 (2011) 29-36.

[6] K. Khan, A. Maqsood, M. Anis-ur-Rehman, M.A. Malik, M. Akram, J. Supercond. Nov. Magn., DOI 10.1007/ s10948-011-1247-9 (2011).

[7] V. L. Mathe and A. D. Sheikh, Physica B 405 (2010) 3594-3598.

[8] E. M. Masoud, Solid State Ionics 253 (2013) 247-252.

[9] Y. Gao, Y. Zhao, M. Fu, Q. Jiao, H. Li, Micro Nano Lett. 8, 2 (2013) 68-69.

[10] J. Xiang, Y. Chu, X. Shen, G. Zhou, Y. Guo, J. Colloid Interf. Sci. 376 (2012) 57-61.

[11] T. Kikuchi, Y. Okazaki, K. Ikeda, JFE Tech. Rept. 6 (2005) 29-34.

[12] O. Mirzaee, A. Shafyei, M. A. Golozar, H. Shokrollahi, J. Alloy. Compd. 461 (2008) 312-315.

[13] D. Sakellari, V. Tsakaloudi, E.K. Polychroniadis, V. Zaspalis, J. Am. Ceram. Soc. 2 (2008) 366-371.

[14] V. L. O. de Brito, S. A. Cunha, L. V. Lemos, C. Bormio Nunes, Sensors 12 (2012) 10086-10096.

[15] I. C. Nlebedim, J. E. Snyder, A. J. Moses, D. C. Jiles, J. Magn. Magn. Mater. 322 (2010) 3938-3942.

[16] I. C. Nlebedim, N. Ranvah, P. I. Williams, Y. Melikhov, F. Anayi, J.E. Snyder, A. J. Moses, D. C. Jiles, J. Magn. Magn. Mater. 321 (2009) 2528-2532.

[17] I. C. Nlebedim, A. J. Moses, D. C. Jiles, J. Magn. Magn. Mater. 343 (2013) 49-54.

[18] C. T. Santos, Evaluation of magnetostriction and microstructural characterization of $\mathrm{Fe}-\mathrm{Sn}$ and $\mathrm{Fe}-\mathrm{V}$ alloy, M.Sc. Diss., Escola de Engenharia de Lorena, USP, Lorena, SP, Brazil (2008).

[19] A. Goldman, Modern ferrite technology. New York: Springer, $2^{\text {nd }}$ ed. (2006) p. 158.

[20] K. J. Kurzydlowski, B. Ralph, The quantitative description of the microstructure of materials, Boca Raton: CRC Press, (1995) p. 275

[21] J. R. Gonçalves, J. Barbosa, P. Sá, J. A. Mendes, A. G. Rolo, B. G. Almeida, Phys. Status Solidi 11-12 (2010) 2720-2723.

[22] R. Benrabaa, H. Boukhlouf, A. Löfberg, A. Rubbens, R. N. Vannier, E. Bordes-Richard, A. Barama, J. Nat. Gas Chem. 21 (2012) 595-604.

[23] M. V. Reddy, T. Yu, C. H. Sow, Z. X. Shen, C. T. Lim, G. V. Subba Rao, B. V. R. Chowdari, Adv. Funct. Mater. 17 (2007) 2792-2799.

[24] E. Caudron, A. Tfayli, C. Monnier, M. Manfait, P. Prognon, D. Pradeau, J. Pharmaceut, Biomed. Analysis 54 (2011) 866-868.

[25] O. N. Shebanova, P. Lazor, J. Solid State Chem. 174 (2003) 424-430.

[26] A. Azizi, H. Yoozbashizadeh, A. Yourdkhani, M. Mohammadi, J. Magn. Magn. Mater. 322 (2010) 56-59.

[27] K. Maaz, W. Khalid, A. Mumtaz, S. K. Hasanain, J. Liu, J. L. Duan, Physica E 41 (2009) 593-599.

[28] Z. P. Niu, Y. Wang, F. S. Li, J. Mater. Sci. 41 (2006) 5726-5730. 
[29] R. J. Harrison and A. Putnis, Am. Mineral. 80 (1995) 213-221.
[30] S. Bhame, Oxide magnetostrictive materials based on cobalt ferrite, Saarbrüken: Lambert Acad. Publ. (2011). (Rec. 03/12/2014, Ac. 30/04/2015) 